\title{
AN OVERVIEW OF IRANIAN ICE REPOSITORIES, AN EXAMPLE OF TRADITIONAL INDIGENOUS ARCHITECTURE
}

\author{
Bahareh HOSSEINI*, Ali NAMAZIAN**
}

Received: 10.02.2012; Final Text: 20.09.2012

Keywords: Ice Repository; Yakhchal; traditional; indigenous architecture; iranian plateau
* Tehran, IRAN.

**Department of Construction, Shahid Beheshti University, IRAN.

\section{INTRODUCTION}

An ice-house (or a Yakh-chal in Persian literally meaning "ice pit", Yakh meaning ice and Chal meaning pit) is a reservoir to store and preserve ice. It was a method which Iranians used in order to preserve ice. It functioned in a similar way as vernacular cisterns: ice was produced in the coldest periods of winter and people would use the preserved ice during long and warm summers. Considering that the climate of a great portion of Iran is hot-arid, summers in these regions are usually long and the air temperature during the day, even in the shade, is unbearable. Therefore, having beverages and ice cream would be a blessing in such weather conditions. Furthermore, it was also essential to keep meat, dairy products and other food stuff fresh and healthy during the hot summer days. As far as we can recognize today, Iranian bio-climatic architecture has provided the needs and essentials of Iranian people. For instance, in temperatures around forty degree Celsius in cities like Kerman or Shiraz or other cities in the hot-arid zone, cold water was always available for people. In other words, Iran's traditional or indigenous architecture fulfilled the suitable indoor climatic condition and comfort for its occupants/inhabitants in all seasons.

Travelers have recorded some notable points about these kind of buildings. Persians' common use of ice and snow for cooling drinks and food was reported by John Fryer in the late seventeenth century: "They mightily covet cool things to the Palate. Wherefore they mix snow, or dissolve ice in their Water, Wine or Sherbets," he wrote (and of Isfahan) ". . the Poor, have they but a Penny in the World, the one half will go for Bread, and dried Grapes, and the other for Snow and Tobacco ..." (Fryer, 1672) Outside Shiraz he saw that ice was stored in "Repositories" which he tantalizingly describes only as "fine buildings" but it seems likely that they were similar to the huge domed structures still to be seen in some parts of Iran. Only a few survived, but most as disintegrating ruins, although they were in common use around fifty years ago (Beazley, 1977). In addition Sir 
Jean Chardin, the French traveler, simply has explained the application of ice repositories in Isfahan in his itinerary:

"People dig a big pitfall and to the north of it, they make square ponds with a depth of around 40 to $50 \mathrm{~cm}$. At nights they fill them with water and in mornings when water is completely frozen, they break the ice into pieces and store them in the pitfall. They chop the ice into smaller pieces because the more chopped, the better it would freeze. They splash water with sprinklers on the pieces of ice at sunset so that the pieces of ice can stick to each other. After at least eight days of continuous work in the same process, Chunks of ice with a thickness of 1.5 to $2 \mathrm{~m}$ are produced. That night neighbors gather to celebrate. Sitting around the ice pits, they play different musical instruments to have more fun. They descend onto the pits, break the ice into pieces and sprinkler water on them to make them stick better.

..."(Chardin, 1677)

This was the procedure through which an ice house would be filled with ice.

\section{HISTORY}

The historical background of Iranian ice repositories is not exactly clear before the Safavid era. So the estimated time according to evidence dates back to before around $400 \mathrm{BCE}$, when engineers had already mastered the art of storing ice in the desert. Most probably by Fryer's time, the practice of storing ice had already been long established, having possibly been introduced by the Mongols. But one cannot be completely sure as to when exactly it became popular among villagers in this part of the world (Ghobadian, 2001). Although using ice has been cited in older texts and historical descriptions, there is no mentioning of how it was produced. According to a drawing by Chardin, one of the ice repositories was near the city of Kashan (Figure 1). The historical background of this structure dates back to 1600s, approximately 400 years ago (Mokhlesi, 1985).

Regarding the record of preserving ice, Samuel W. Mathews, the Former editor of National Geographic Magazine states that:

"Chinese used repositories to store ice many centuries B.C. and ancient Greeks and Romans would store snow underground, covering it with straw. They would use it when they wanted to have cold wine. However there was a belief that this kind of ice was not clean, .Having said that, a Greek Physician (4 to 5 B.C.) referred to it as an unhygienic drink on melted ice." (Mathews, 1987)

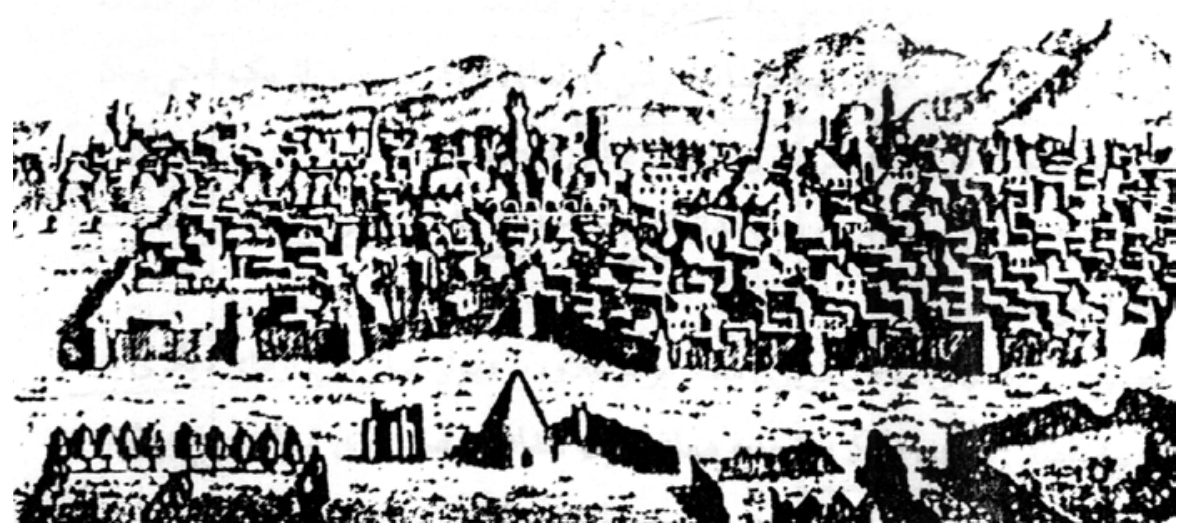


One of the basic concerns of traditional architecture in Iran was to create safe living conditions for most people, bearing in mind the climatic features of each region. Ice repositories were public, so all people could use ice in Iran. It was especially desirable for the European noblemen of the eighteenth century to have ice during summers. A traveler to this region states that the method of preserving ice in Iran was so professional yet simple that even poor people could afford it. One of the German travelers to the city of Isfahan wrote:
"There were plenty of Yakhchals in Isfahan; some of them were for private use. Nevertheless, the poor could also use the Yakhchal to cool water. Sherbets and fruit were preserved with ice in all shops. Huge chunks of ice were carried by donkeys and sold all over the province. In Isfahan, people could buy ice either in the bazaar or straight from Yakhchal building" (Ernest Holster, 1870).

As mentioned, most of the existing ice repositories are the remains of the after Safavid period. The most reliable documents about these buildings are the sketches of an explorer during the Safavid's reign or after that. Here are some examples of what is the remnant of those drawings.

Krenelin Bervin was a dutch traveler who came to Iran and drew one of the ice repositories in the city of Qom (Figure 2). This figure is one of the most important historical documents from the Safavid era. In this picture the ice house has conical dome with a great wall. Another picture is one of the works of Jules Lawrence in 1884 which shows one of the Safavid caravanserais near the city of Garmsar (Figure 3). A great ice house with its nearly destroyed shadow wall is recognizable (Mokhlesi, 1985).

\section{LOCATIONS (GEOGRAPHY)}

Ice repositories in Iran were common in areas that had suitable condition for producing ice, which means the feasibility of water freezing during the cold nights. It was also prevalent in regions where ice could be obtained naturally. In cold areas, ice was collected from shadowed hillsides of the mountains and then it was transferred to the ice house to be kept till the hot seasons. Since in the southern parts of Iran the temperature rarely dropped below zero, there was no ice house there. In addition, at Caspian shores in the north of Iran, no ice house is seen, because of the humidity and low temperature fluctuation during day and night. On these shores, it is very scarce to go through freezing point and the temperature does not get cold enough to provide ice. But like other regions in Iran, people condensed snow at the time of precipitation, put them within the layers of wicker or straw and had them buried underground to be used in summers (Kasmaie, 2006).

\section{ARCHITECTURAL ELEMENTS}

The ice house principles are as simple as mentioned, but this simplicity is to meet such crucial requirements and that's where Iranian ancestor's sagacity clarifies. Ice house's structure may seem simple at first glance but it can be considered a beneficial building, subtly resulting in convenience of the people around.

The structure of the Yakhchals generally consists of three main parts: A great shading wall, the provision pool, and the ice reservoir, each of which will be introduced as follows: 
Figure 2. A sketch by Krenelin bervin from the city of Qom, The ice house and its great shading wall is seen on the left (Mokhlesi, 1985).

Figure 3. One of the safavid caravanserais near the city of Garmsar drawn by Jules Lawrence (Mokhlesi, 1985).
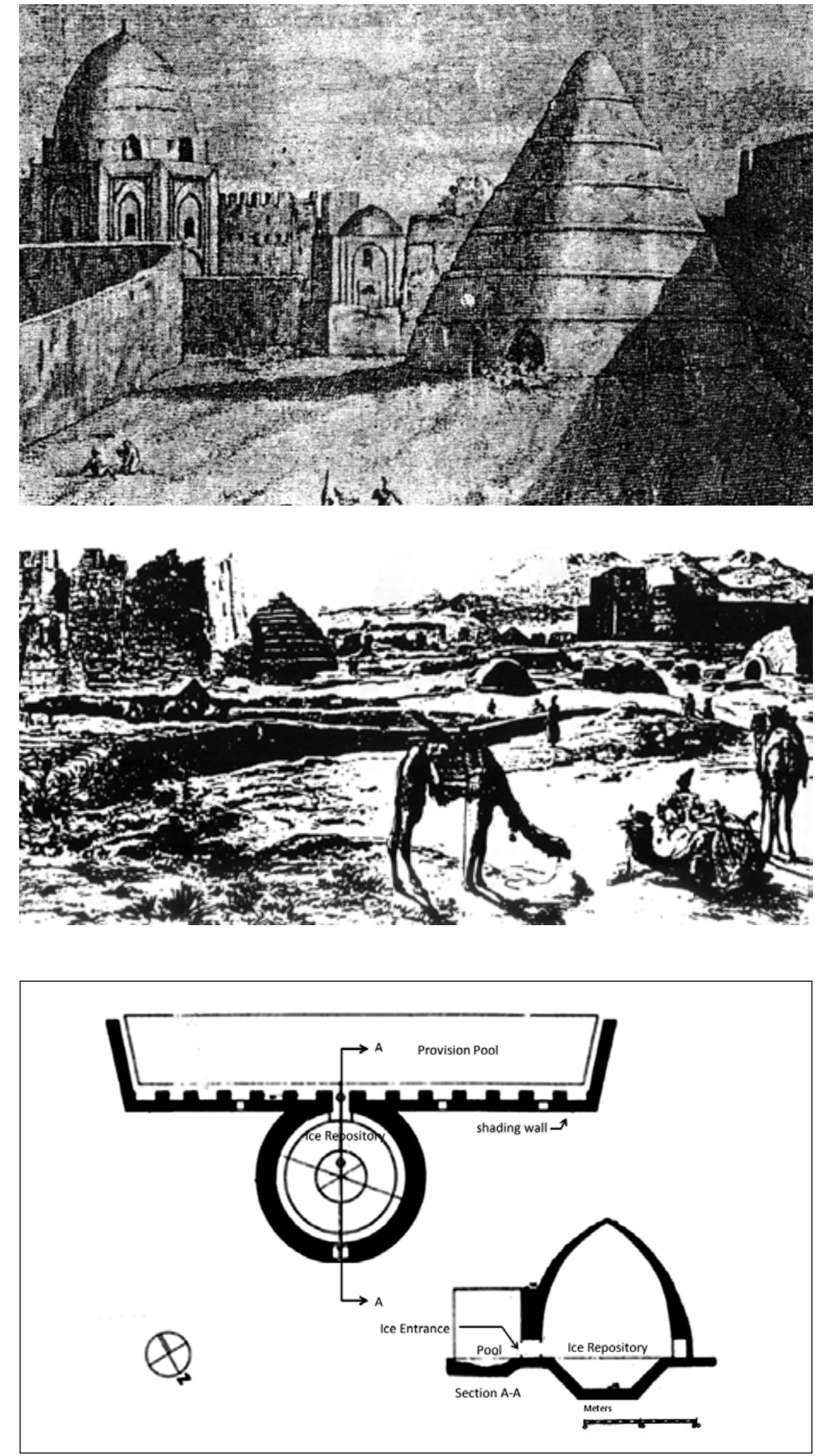

Figure $4 \mathrm{a}, \mathbf{4 b}$. Ice house of Meibod in Yazd, This structure with a height of $15 \mathrm{~m}$. is one of the tallest structures in the city (Ghobadian, 2001).

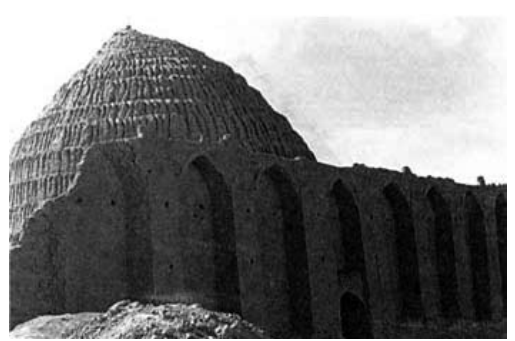




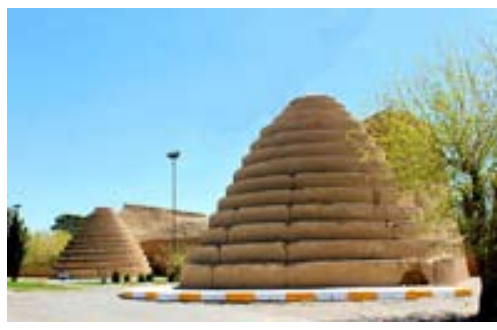

Figure $5 \mathbf{a}, \mathbf{5 b}$. Ice houses at Sirjan and their plans, restored recently ( 5 a by Hosseini ,2010, 5 b by Beazley, 1977).
Figure 6. Two kinds of shading walls in the examples from city of Yazd (Mokhlesi, 1985).
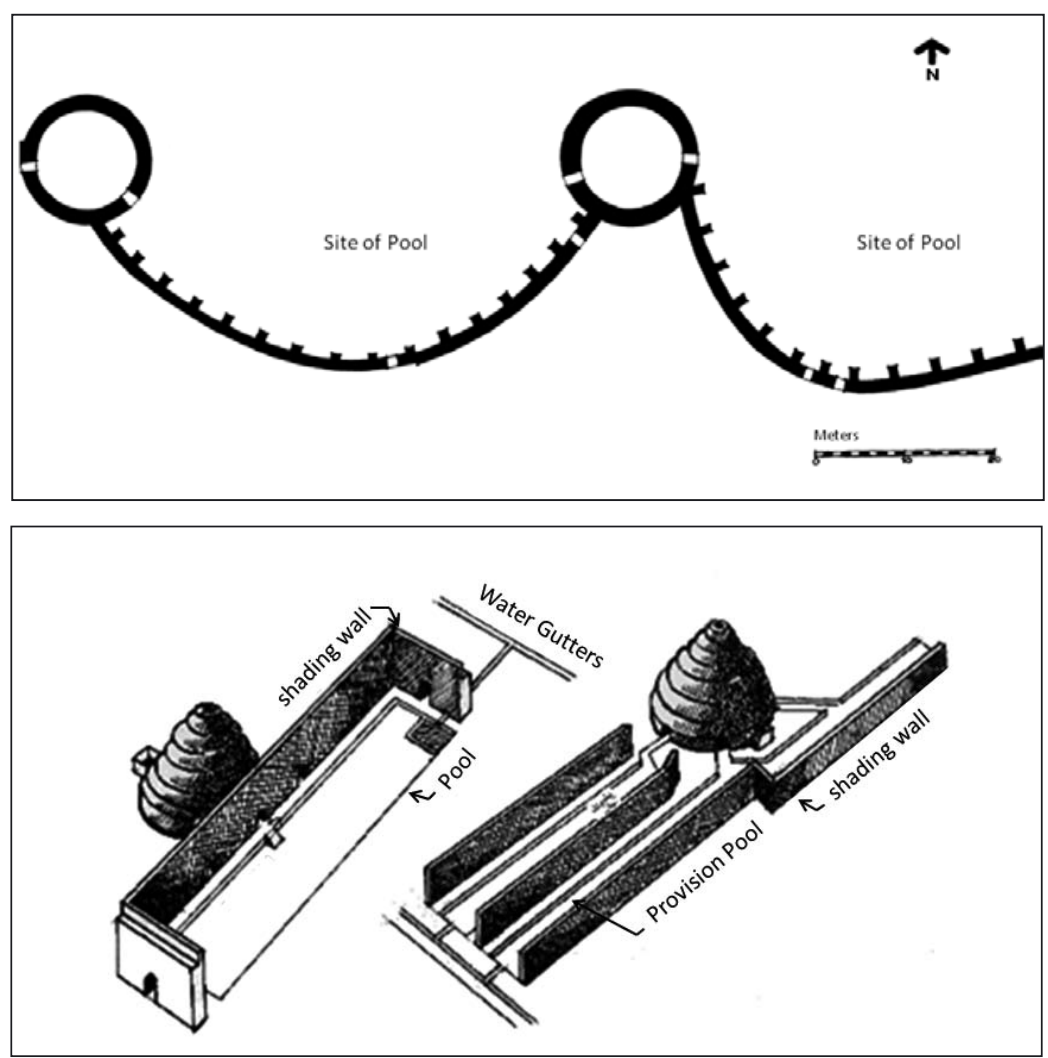

\section{The Shading Wall}

The shading wall is a long and great wall located along each ice house (Figure $4 a, 4 b$ ), casting a long shadow on the shallow channel to its north. Based on the fact that Iran is located in the northern hemisphere, the shading wall always stands to the south of the ice-making channel in order to have the best position to spread shadow all over its surface. Therefore it stretches from the east to the west. The enormous height of this wall which comes up to nearly $10 \mathrm{~m}$. height sometimes, prevents the sun's radiation from shining on the frozen water in the front pond. The shading wall gives workers more time to attempt to transfer pieces of ices from ponds to the reservoir during the hot days of summer. It is beneficial because the temperature difference between the sun-lit and the shaded area in hot and dry regions is about 15-20 degrees (Mokhlesi, 1985).

Shading walls were thick at low levels but gradually became thinner as it got to high levels in order to get self stable. Sometimes it was extended perpendicularly at both ends. This extension was about 1 to $2 \mathrm{~m}$. and northward to decrease sunset and sunshine glare to the pools. In some examples the shading walls curved to provide extra shading. The walls of the double ice-house at Sirjan were designed in this method (Figure 5). The walls which connected these two created a curved shape plan and provided a vaster site for the pools. This action also helped workers to secure themselves in confronting with cold blasts, during the ice making operation at cold winter nights and dawns. Sometimes there were some hollowed arch shapes in the wall. It was not only to diminish the load on the foundation, but to extricate it from being flat and boring. To add more stability to the shading walls, some buttresses were added to the south of 


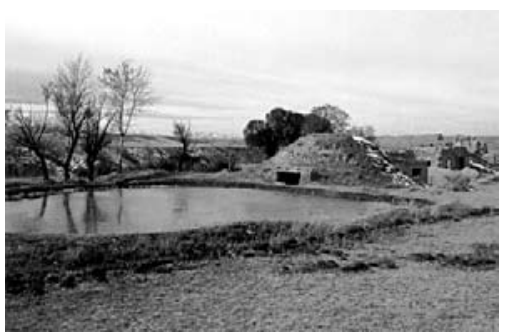

Figure 7. Alaghbeig ice repository without the shading wall with its great pool in front of it (Hosseini, 2011). the wall occasionally. In some desert areas, usually central parts of Iran, several shading walls were erected, especially when their storage was bigger, so they could afford much more ice (Figure 6).

\section{The Provision Pool}

To let water freeze needed some temporary shallow sluice. Although providing water in such climate is not easy, the ingenious Persian people did not give up such extraordinary process which is ice processing and preserving it in such arid climate. Generally water was procured from water systems known as qanats (traditional local system for transferring water) or some rivulets in the region or other sources and conducted to some ponds located just north of the wall. Square in shape, the channel was approximately $100 \mathrm{~m} . \mathrm{X} 10 \mathrm{~m}$. with a depth of about $40-50 \mathrm{~cm}$. They dug it parallel to the great wall in order to get more shade. This pool was used as the preparation place for ice during cold winter nights. Some times in colder areas pool and the storage were the main parts of the ice house and the shading wall was eliminated. Since cloudy sky in these regions functioned as an insulation layer and no wall was needed anymore. (Figure 7) No special material was used to finish the channel surface. People draw water into flat furrowed fields as Chardin has mentioned in his itinerary. They made high adobe or mud walls to keep the area shaded during the day. As a result at nights, its temperature is lower than its neighboring region and water can freeze more quickly. Coldness of winter takes the heat of water away at night, resulting in ice being formed and at dawn, people chop the ice into pieces and transfer it to the main structure of ice house which is the southern pitfall that is introduced in the following.

\section{The Ice Reservoir}

These reservoirs are usually located behind the shading wall and at its south. One can access them through one or several entrances from the northern part (the pool area). Non-conductors were essential in order to keep and store ice for a long time in so doing. People preserve ice in an underground well. Three kinds of wells were prevalent in Iran that will be described as follows:

\section{Vaulted Yakhchals}

In north-eastern region and the central desert, people constructed a big adobe vault above an almost great pit. It was somewhat cone shaped. The dimensions of the pitfall were different. One of the biggest examples of this kind is located in the city of Meibod in Yazd province. (Figure $4 a, 4 b$ ) The diameter of its vault was $13 \mathrm{~m}$. and the pit had a depth of $6 \mathrm{~m}$. The pit was surrounded by a vault whose thickness diminishes from beneath to the top to provide more endurance and stability, so it weighs less and the gravity center located in a lower height. This point also reduced the construction costs as less material and labor forces were employed. The height of the vault in Meibod was almost $15 \mathrm{~m}$. Its thickness reduced from the bottom (around $240 \mathrm{~cm}$.) to the top $(20 \mathrm{~cm}$.), at which point it was equal to the length of an adobe piece. One of the advantages of these vaults was that they could be built step-liked (Figure 8). They used stairs to help workers to cover the external crust of the vault with thatch to protect it from rain, snow, sun and atmospheric variations. They built smaller stairs between these stairs to make it possible for workers to ply. So people could maintain or repair them easily. In the head of summers especially in central regions, the sun heats the Yakhchal dome. This method was also employed in order to prevent the ice stored to melt during hot seasons. When the temperature 

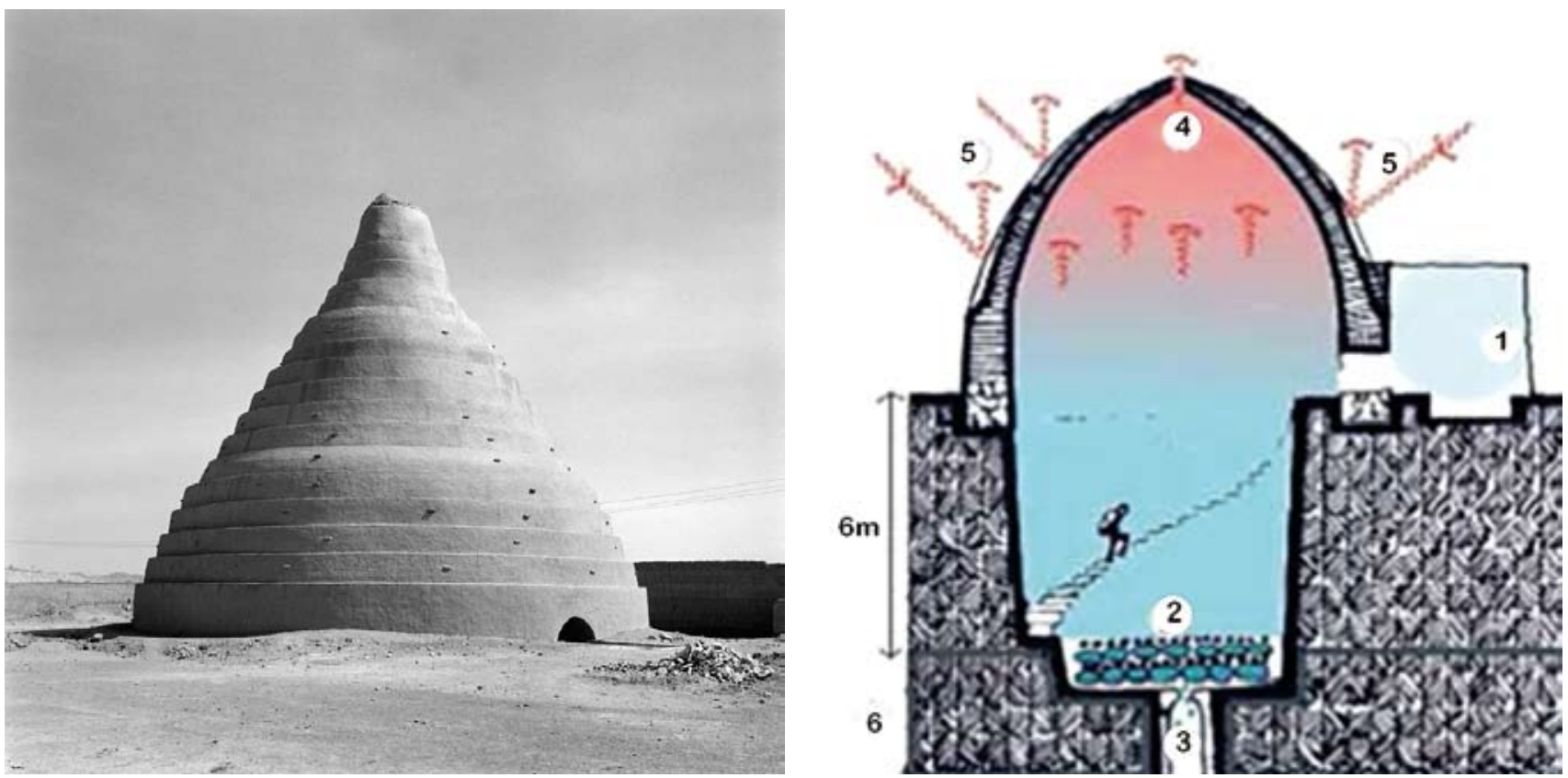

Figure 8. Vaulted Yakhchal in abarku-Yazd (Lynn Davis, 2001).

Figure 9. General section of the reservoir of a vaulted ice house (Okhovat, 2011).

1. The provision area, consisting the provision ponds and the high shading walls scattering shadow on the pieces of ice made during the coldness of the winter nights.

2. The ice main repository where pieces of wood and straw are used between each layer of ice to avoid sticking to each other.

3. The predicted well at the bottom of the repository in order to vacate the melted ice.

4. Cold and fresh air goes down. So warm air goes up and exit from a hole on the top of the dome.

5. Large thickness of container's dome, using masonry (with low coefficient of heat transfer) and its external thatched coverage have the role of thermal insulation to prevent thermal conductivity.

6. As a result of "Earth's Seasonal Heat Delay Effect", the container keeps it's winter's condition during hot seasons (According to this fact, temperature of 6 meters below ground level has a constant amount of the average temperature of summer and winter).

Figure 10a ,10b. Figure 10a shows a southern entrances of a ice house which was used by the person in charge, and the $10 \mathrm{~b}$ looks through the inside of a ice house which stairs and sloped surfaces are designed to help man and ice transfer (Andrew Schnider, 2010). augmented, just the upper air, trapped in the structure, got warm and the lower layers of it remained cool (Figure 9). These high vaults were regarded as the highest or one of the highest constructions in the villages. In addition a well usually was considered beneath the main pit to let the melted water poured into it because the melted water causes the ice melt too.

In western and north-western regions of Iran, the weather was/is cooler than in the desert. So fewer vaulted Yakhchals can be seen there and using natural ice provided from shadowed foothills was common.

Normally Yakhchals had two entrances. One of them was between the freezing area and the pitfall. Another one was at the south of the ice house. (Figure 10a, 10b). The north door was utilized to transfer pieces of ices via a sloped surface to the pitfall in winters. The southern door was usually opened at summers in order to serve and sell ice. A stair case was built at the southern part of the pitfall for the person in charge to let him access the lower parts of the pit.
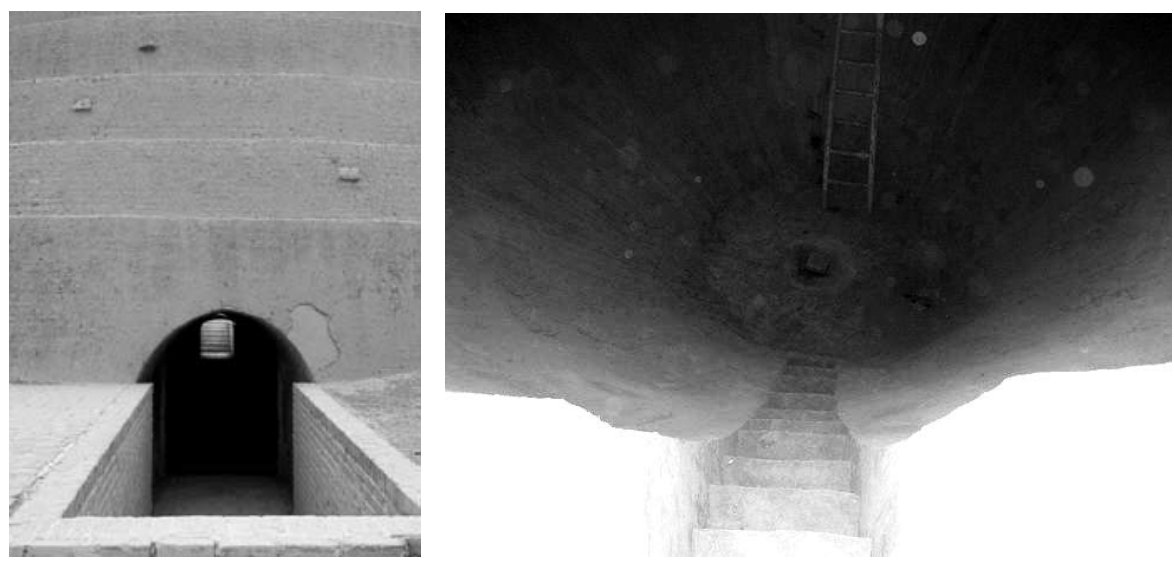
Figure 11. Plan and section of an underground Yakhchal (Ghobadian, 2001).
Figure 12a, 12b. An under ground ice house (left) and its plans and sections (right) in Orumie (Ghobadian, 2001).

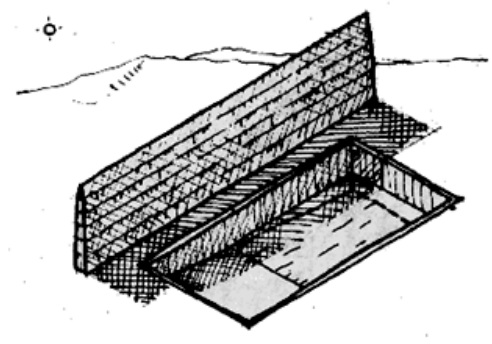

Figure 13. A kind of roofless Yakhchal which was used around the city of Isfahan. (Ghobadian, 2001).
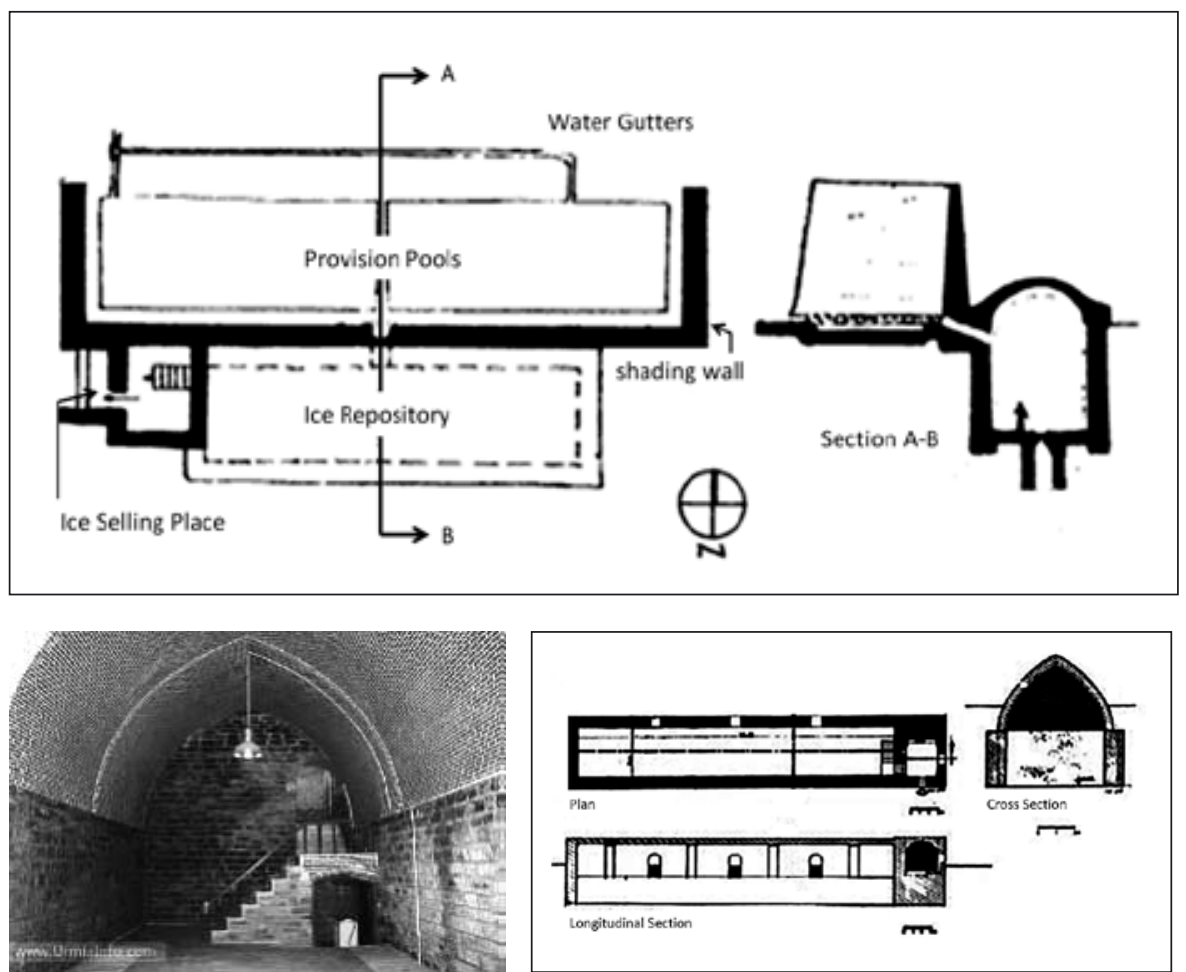

\section{Underground Yakhchals}

Another kind of Yakhchal was built in north-central and north-western parts of Iran and its function was similar to the vaulted Yakhchals but its physical appearance was different. Most parts of this kind of ice house lay underground (Figure 11). Its thick wall was made of brick and spall with hydraulic mortar like lime, sand, cement and sarooj (which is a vernacular mortar out of clay, water and egg's white part). Its roof was often of brick in the form of barrel vault or ribbed vault and it usually resembled a tunnel (Figure 12a, 12b). Having frozen in ponds, the ice was then poured into Yakhchal through a value beneath arches. Every time ice was poured, they sprinkled water on it to make it homogenous. In this kind of Yakhchal, ice layers were not covered with straw due to the region's cold climate which made ice collecting an easy job even during summers. Ice was delivered through the southern door, which was connected to the pitfall through stairs.

\section{$\underline{\text { Roofless Yakhchals }}$}

The third kind of Yakhchal, called "Roofless Yakhchals", was without roof. It was built in Isfahan (Figure 13). Like other kinds of ice repositories, this ice house was used up until 40-50 years ago. It consisted of just two main parts, the shading wall and the pools in front of it. In this method, the provision pools were considered as the storage place for the ice. The shading wall, with a height of 4 to $5 \mathrm{~m}$., had a length of $12 \mathrm{~m}$. To the north of it, people had built a $5 \times 5 \times 12 \mathrm{~m}$ pool.

As Sir Chardin points out in his itinerary people would pour ice into Yakhchal. First they broke it into smaller pieces, and then they poured water on it to get a homogenous mass of ice. Afterward they would put wicker or straw on it and next another layer of ice. Therefore, a layer of straw or wicker was placed between the two layers of ice. As a result in summers 
during the peak of sales, it would be easier to break the ice layers than when it was stored in an entire pool. Moreover when they wanted to pick up a layer of ice, the wicker beneath functioned as a non-conductor for the rest of ice in the pool. Putting straw and wicker between layers of ice was also common when using vaulted Yakhchal.

When the sales ended, people would cover the surface of ice with 1 to $2 \mathrm{~m}$. of straw and gradually used it in hot weather. The capacity of this kind of Yakhchal in Isfahan was so great that usually some ice would remain for the next year but as the author points out there is no such Yakhchal anymore.

\section{THE OBSOLESCENCE OF ICE REPOSITORIES}

Unfortunately almost none of these structures are under use anymore. With propagation of common refrigerators and penetration of industry to homes, ice repositories turned out to be some abandoned eyesores which are unpleasant even to approach let alone to investigate. Some of fortunate ones are restored in the city of Kerman (Figure 5) and in the city of Orumie to satisfy the curious visitors investigating them. Some examples are being used for other purposes such as tea house or sheep-pen with miserable appearance; but most of them are doomed to be left in adverse conditions with no protection. Some of the reasons that led to their obsolescence are listed below:

- Fading of ice repositories, social and economical significance due to the widespread usage of common refrigerators led to their abandonment. Modernization of ice making industry individualized every citizen's need for ice and fresh food. This was truly the main reason for not having them today.

- Erosion was one of the other important reasons which threatened their existence. Desert storms, carrying huge amount of sand and gravel, caused a lot of erosion to the structure of ice repositories, especially as they were isolated in vast desert regions. Moisture penetration derived from water drawn into the pools or water from melting ice have had destructive effects too. So in order to keep these buildings inviolable from erosion, it was required to maintain them frequently, but due to the shortage of labor force caused by irregular immigration to the cities and promotion of using common refrigerators they became effected.

- The contamination of ice obtained from ice repositories was another reason that made ice repositories abandoned as Yakhchal's ice was usually merged with dust and soil because ice was developed in open areas. Also channels and ponds were dug in the soil and were used without any finishing material. Therefore people found other sources that were healthier for procuring ice.

\section{CONCLUSION}

Iran's traditional architecture is derived from its climatic conditions and evolved accordingly during centuries. Thus, climate as the most effective factor has been affecting indigenous architectural structures including ice repositories or Yakhchals in this region. These kinds of buildings granted people with convenience in those harsh and severe climatic conditions. These buildings benefitted all villagers. it means that they were profitable to all of the villagers as a source of revenue especially for the people in 
charge who sold ice to the passengers. Therefore during the ice making period, usually most of the local people would collaborate in making and harvesting ice and this illustrates a common alliance in a community affected by such a building.

Ice house in Iran was one of the prominent examples of vernacular architecture which arose from ordinary people with limited facility and knowledge. The significant point to note about these ice repositories is that they required little work and maintenance efforts. During the whole ice making and preserving process there was no need to consume any kind of energy except manpower. Thus from technical point of view, they were quite beneficial. But their application is not proposed today anymore.

Mainly because of the vast usage of industrial refrigerators that are much cleaner and more comfortable.

The investigation of these traditional ice repositories can be an attractive approach for today's achievements. It is hoped that more contrivance be taken in order for the revival of such buildings with today's technology and insight especially when they can help in the course of dealing with global energy crisis. The simple technique of producing and preserving ice in these buildings can be an interesting future investigation for new architectural projects in which the subject of getting the desirable ventilation out of the passively procured ice during the hot days of the summer is an enlightening inception.

\section{REFERENCES}

AGHDABIGLO, Z. (2001) Passive cooling systems, PhD thesis, Sydney University; 76-9.

BEAZLEY, E. (1977) Some vernacular buildings of the Iranian plateau, British Institute of Persian Studies, Iran, v:15; 89-102.

BOURGEOIS J, PELOS C. (1983) Spectacular Vernacular: A New Appreciation of Traditional Desert Architecture, Peregrino Smith Books, New York, 67-71.

CHARDIN,J. (1677) Voyages en Perse et autres lieux de l'Orient

Cultural Research Association (2007) The Iranian Atlas of Vernacular Architecture, Cultural Research Association; 71, 93, 114.

DAVIS, L. (2006) Persia, Paris: Galerie Karsten Greve, (Exhibition Catalog).

DIEULAFOY, J. (1887) La Perse, la Chaldee et la Susiane, Paris, P.680.

FRYER, J. (1963) A New Account of the East Indies and Persia Being Nine Years Travels, 1672-81, Cultural Research Association, Tehran; 149.

GHOBADIAN, V. (2001) Climatic Analysis of the Iranian Traditional Buildings, Tehran University Publications; Tehran; 308-37.

HERBERT T. (1928) Travels in Persia, 1627-29, Broadway Travelers' Edition; London, 143.

HOLSTER, E. (1870) Iran in hundred and thirteen years ago; 47.

HYDE, R. (2000) Climatic Responsive Design, E \& FN Spon Publications, New York; 97-112.

KASMAIE, M. (2006). Climate and Architecture, the Iranian Construction-Co; Tehran; 54-8. 
LAMBTON, A. (1953) Landlord and Peasant in Persia, Broadway Travelers' Edition; London; 143.

LOCKE, G. (1975) “Icehouse”, National Trust Newsletter, n:24; 20.

MATTHEWS, S.W. (1987) National Geographic, v. 171, n:1; 92.

MOKHLESI, M. (1985) Traditional Refrigerators, the Forgotten Masterpieces, the Second Congress on Architecture and Urban Planning History, $\mathrm{v}: 2,685-98$.

MURAKAMI, S. (2008) Environmental Assessment of Vernacular Architecture, Keio University Press, Keio, 67.

OKHOVAT, H. et al. (2011) A Research on historical and cultural buildings in Iranian vernacular architecture, Architecture, City and Environment, v: $17 ; 37-58$

SCHNIDER, A. http://www.andrewschneider.com/gallery/seriesIranToYazd/index.html

STRONACH, D. B. (1973) The first international colloquy on the conservation of mud brick monuments, published by ICOMOS, Yazd; 64-73.

TAVASSOLI, M. (1974) Architecture of hot arid climate, Tehran University, Tehran; 38.

Alındı: 10.02.2012; Son Metin: 20.09.2012

Anahtar Sözcükler: Buz Deposu; Yakçal; geleneksel; yöresel mimarlık; İran platosu.

\section{İRAN BUZ DEPOLARINA GENEL BİR BAKIŞ, BİR GELENEKSEL YÖRESEL MIMARLIK ÖRNEĞİ}

Bu makale İran yöresel mimarisindeki bazı antik buz depolarının yerinin keşfedilmesi yönünde bir çabadır. İran yöresel mimarisinin en temel özelliklerinden biri sert çevresel etkenlerle baş etmek için basit ama ustaca tekniklerin kullanılmasıdır. İran'ın sıcak ve kurak ikliminde dayanıksız yiyecek maddelerinin korunması ve sıcak havalarda buzun depolanması, yaşamın sürdürülebilmesi için önemli bir konuydu. Atalarımız bu konuyu yaratıcı bir çözümle ele almışlardı; buz deposu ya da yöresel adıyla Yakçal, İran'da hiçbir etkin enerji kaynağı kullanmadan buz üretebilen ve koruyabilen antik bir buzdolabı türüydü. İşlem basitti; soğuk kış akşamlarında sağlanan su genellikle derin kanallarda donmaya bırakılır, bir sonraki uzun sıcak yaz günlerine kadar muhafaza edilmek üzere bir buz deposuna aktarılırdı.

Yöresel iklimle baş etme ihtiyacı, çok kısıtlı kaynakları olan bu insanları yaşamlarını tehdit eden bir konuda böyle mimari bir çözüm bulmaya itmişti ki bu da "buz yapan yapı" ya da bilinen adıyla "Buz Evi"ydi. Bir başka deyişle kıtlık, İranlıları yaratıcı çözümler bulmaya zorlamıştı. Yüzyıllar boyunca insanlar bu dev yapıların yardımıyla buz üretip, muhafaza edip kullanabildiler. Bu makalede bu tür bir buz deposunun çeşitli türleri araştırılmakta ve sunulmaktadır. Aynı zamanda bu yapıların avantajları ve dezavantajları gösterilmeye ve yöresel mimari örnekleri olarak günümüz bilgi ve koşullarında önemlerinin belirlenmesine çalışılmaktadır. 
BAHAREH HOSSEINI, B.Arch ,

Graduated from Shahid Beheshti University (2012), currently works as an architect in Memaran Consulting Engineers in Tehran (2010-2012), has few articles related to Iranian vernacular architecture, research interests include islamic architecture and urbanism, architecture and urban history and middle eastern studies, bah.hosseini@mail.sbu.ac.ir

ALI NAMAZIAN, B.Arch, M.Arch, Ph.D.

Graduated from the Houston University, Texas, received his M.Sc. from construction department at Houston University, earned his Ph.D. Degree in Environmental Design in A\&M University, Texas, currently works as a lecturer in Shahid Beheshti University, Department of Construction, research interests include history of architecture, solar energy applications, architectural psychology. a-namazian@sbu.ac.ir 